
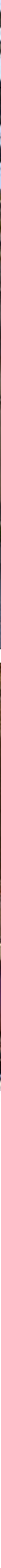

PneumoUpdate 2016

\title{
Fortbildung in edlem Ambiente
}

In angenehmer Atmosphäre trafen sich Pneumologen/-innen aus

Deutschland, Österreich und der Schweiz in Wiesbaden, um aktuelle

Erkenntnisse ihres Fachgebiets festzuklopfen und zu ergänzen. Beliebt

war dabei wieder das gewichtige "Handbuch" mit den vorgestellten

Studien, das viele noch dem eBook vorziehen. Und natürlich kam auch das Zeitgeschehen hin und wieder zur Sprache - mal mehr, mal weniger scherzhaft. Die Termine im nächsten Jahr: 17. - 18.11.2017 (Wiesbaden, Kurhaus) und 24. - 25.11.2017 (Berlin, Langenbeck-Virchow-Haus).
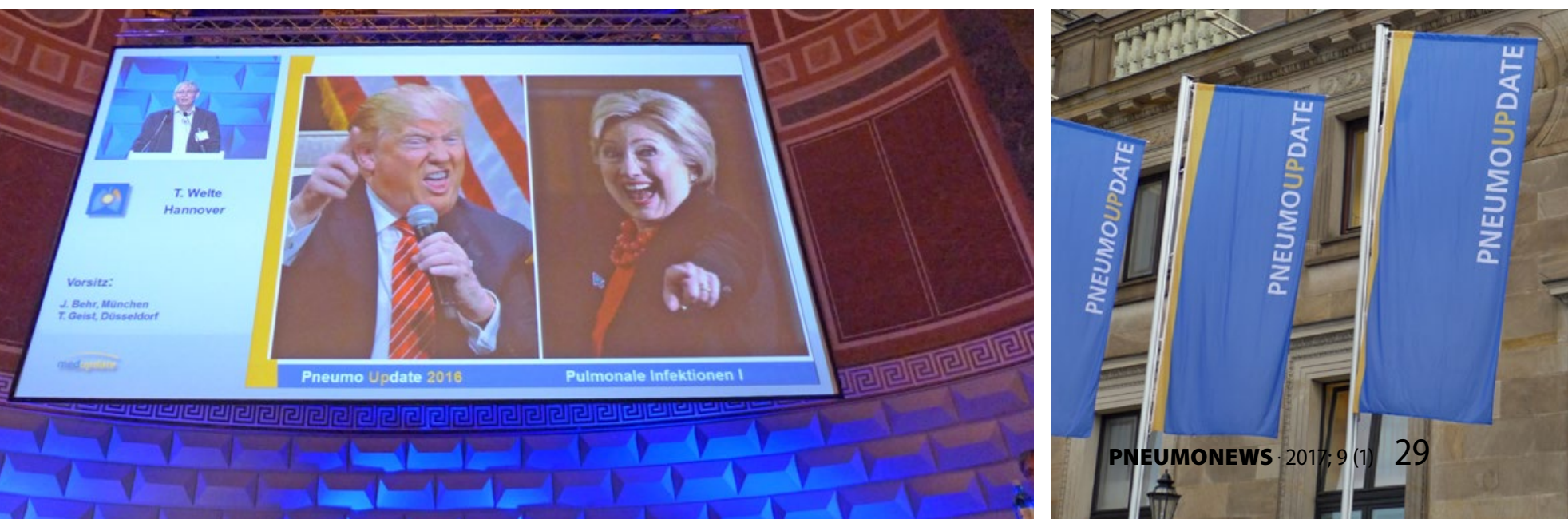